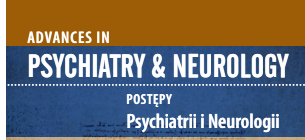

Correspondence to/

Adres do korespondencji:

Aleksandra Kielan

Zakład Zdrowia Publicznego

Warszawski Uniwersytet Medyczny

ul. Jana Nielubowicza 5

02-097 Warszawa, Polska

e-mail: aleksandra@kielan.eu

Submitted/Otrzymano: 21.10.2019

Accepted/Przyjęto do druku: 19.01.2020

\section{DEPRESSION IN MALES - SPECIFICITY, AETIOLOGY, RELATIONSHIPS WITH SUICIDAL TENDENCIES AND THE PSYCHOACTIVE SUBSTANCES USAGE: LITERATURE OVERVIEW}

\author{
DEPRESJA U MĘŻCZYZN - SPECYFIKA, \\ ETIOLOGIA I ZWIAZZKI Z TENDENCJAMI \\ SAMOBÓJCZYMI ORAZ UŻYWANIEM \\ SUBSTANCJI PSYCHOAKTYWNYCH: \\ PRZEGLĄD PIŚMIENNICTWA
}

\author{
Aleksandra Kielan 1,2, Dagny Gorostiza ${ }^{3}$, Anna Mosiołek4, \\ Jan Chodkiewicz ${ }^{5}$, Łukasz Święcicki ${ }^{6}$, \\ Bożena Walewska-Zielecka ${ }^{1}$ \\ 'Department of Public Health, Faculty of Health Sciences, Medical University \\ of Warsaw, Warsaw, Poland \\ ${ }^{2}$ Polish Suicidological Society, Poland \\ ${ }^{3}$ Social Welfare Center of the Ursus District of the Capital City of Warsaw, Poland \\ ${ }^{4}$ Department of Psychiatry, Faculty of Health Sciences, Medical University \\ of Warsaw, Warsaw, Poland \\ ${ }^{5}$ Department of Psychoprophylaxis and Addiction Psychology, Institute \\ of Psychology, University of Lodz, Lodz, Poland \\ ${ }^{6} 2^{\text {nd }}$ Department of Psychiatry, Institute of Psychiatry and Neurology, Warsaw, Poland
}

\author{
'Zakład Zdrowia Publicznego, Wydział Nauki o Zdrowiu, Warszawski Uniwersytet \\ Medyczny, Warszawa, Polska \\ ${ }^{2}$ Polskie Towarzystwo Suicydologiczne, Polska \\ ${ }^{3}$ Ośrodek Pomocy Społecznej Dzielnicy Ursus m.st. Warszawy, Polska \\ ${ }^{4}$ Klinika Psychiatryczna, Wydział Nauki o Zdrowiu, Warszawski Uniwersytet \\ Medyczny, Warszawa, Polska \\ 5Zakład Psychoprofilaktyki i Psychologii Uzależnień, Instyłut Psychologii, \\ Uniwersytet Łódzki, Łódź, Polska \\ '/l Klinika Psychiatryczna, Instytut Psychiatrii i Neurologii, Warszawa, Polska
}

\begin{abstract}
Purpose: To raise awareness about depressive disorders occurring in men and to define the causes that influence them.

Views: Depression and suicide attempts are observed more often among women. However, men far more often commit suicide. Research shows correlation between low incidence of diagnosed depressive disorders and high incidence of suicidal deaths in men. Depression in men may have different causes and symptoms than depression in women. Numerous research studies suggest the existence of the "syndrome of male depression" where - apart from typical symptoms - there are often additional symptoms, such as anger, impulsiveness, substance abuse and antisocial behaviours. Sometimes similar behaviours can occur among depressive women. Mostly, however, women express their pain with emotions while men are concentrating on actions. Men also seek a specialist's help significantly less frequently. Men treat the abuse of psychoactive substances as a form of self-medication more often than women do. Alcohol addiction coexisting with depression increases the risk of suicide attempt in men.

Conclusions: The literature review proves the complexity of the problem of depressive disorders occurring in men. There is a close correlation between depression, addictions and suicides. Improvements in prevention, diagnosis and treatment of any of these problems may positively influence others, too. These issues require further analysis and research. In this paper, it will be a representation of the male part of the Polish population.
\end{abstract}

Key words: depressive disorders, suicide, substance abuse. 
Depression in males - specificity, aetiology, relationships with suicidal tendencies and the psychoactive substances usage - literature overview Depresja u mężczyzn - specyfika, etiologia i zwiq̨zki z tendencjami samobójczymi oraz używaniem substancji psychoaktywnych - przegląd piśmiennictwa

\section{Streszczenie}

Cel: Zwrócenie uwagi na zaburzenia depresyjne występujące w grupie mężczyzn i uwarunkowania, które wpływają na ich przebieg. Poglądy: Depresja i próby samobójcze są częściej obserwowane wśród kobiet, jednakże zdecydowanie częściej śmiercią samobójczą umierają mężczyźni. Występująca wśród mężczyzn relacja między niskim odsetkiem diagnozowanych zaburzeń depresyjnych i wysokim odsetkiem śmierci samobójczych jest sygnalizowana w literaturze naukowej. Depresja u mężczyzn może mieć inny obraz kliniczny niż depresja występująca wśród kobiet. Wiele badań sugeruje istnienie „syndromu męskiej depresji”, gdzie wraz z typowymi objawami epizodu depresyjnego o dużym nasileniu obserwuje się również takie nasilone objawy, jak: złość, impulsywność, nadużywanie substancji i zachowania antyspołeczne (nie oznacza to jednak, że tego typu objawy nie występują u kobiet z depresją). Specyficzne dla mężczyzn cechy zaburzeń depresyjnych mogą być uzewnętrznianiem przez nich cierpienia w postaci aktywności ukierunkowanej na działanie (na przykład podejmowanie ryzykownych zachowań). Istotne jest również znacząco rzadsze poszukiwanie przez chorujących na depresję mężczyzn specjalistycznej pomocy. Mężczyźni częściej niż kobiety traktują nadużywanie środków psychoaktywnych jako formę samoleczenia. Współwystępowanie uzależnienia od alkoholu z depresją wielokrotnie zwiększa ryzyko podjęcia przez mężczyznę próby samobójczej.

Wnioski: Przegląd piśmiennictwa potwierdza złożoność problemu zaburzeń depresyjnych występujących wśród mężczyzn i ścisłą zależność między depresją, uzależnieniami oraz samobójstwami. Poprawa w zakresie jakości profilaktyki, diagnozowania i leczenia któregokolwiek z tych problemów może mieć pozytywny wpływ na pozostałe zmienne. Temat ten wymaga dalszej analizy i przeprowadzenia badania, którego wyniki będą reprezentatywne dla męskiej części populacji Polski.

Słowa kluczowe: zaburzenia depresyjne, samobójstwo, nadużywanie substancji.

\section{INTRODUCTION}

The results of "The Global Burden of Disease Study 2015", conducted by the World Health Organisation, indicates that for the residents of Poland, depression takes the third place in ten most common causes of lost years of life in health due to YLDs (years lived with disability) [1].

Typical symptoms of depression are not necessarily observed in all patients. Depression is diagnosed almost twice more often among women than in men [2]. Some peices of research show that depression in men is often manifested by unspecific symptoms, which makes it difficult to diagnose and to estimate a real number of patients [3]. Depressive disorders have close connection with suicidal tendencies; in the majority of countries, suicide is one of the most frequent causes of deaths among depressive patients [4]. Moreover, among people in the age range between 15 and 29 , suicide is the second cause of death [5]. The number of suicides in Poland (despite the noteworthy decline between 2015 and 2018) is very high, exceeding five thousand people annually (even exceeding the number of car accident victims). Men commit suicide much more often than women $(6: 1)$ [6].

Men undertake suicide attempts under the influence of alcohol or drugs and this is far more often than women do. A stronger correlation is noticed between alcohol abuse/ addiction and depressive disorders in men $[7,8]$. Currently, there are more research studies about depression in women $(3: 1)$ than about depression in men [9].

This study is a review of the literature about correlations between depression, addictions and suicidal tendencies occurring in men. The main aim was to raise aware-

\section{WPROWADZENIE}

Wyniki „The Global Burden of Disease 2015 Study” przeprowadzonego przez Światową Organizację Zdrowia wskazują, że wśród dziesięciu najważniejszych dla mieszkańców Polski przyczyn utraconych lat życia w zdrowiu $\mathrm{z}$ powodu ograniczonej sprawności (years lived with disability - YLDs) depresja znajduje się na trzecim miejscu [1].

Typowe objawy depresji nie zawsze muszą wystąpić u wszystkich chorych. Depresję rozpoznaje się niemal dwukrotnie częściej wśród kobiet niż wśród mężczyzn [2]. Badania dowodzą, że u mężczyzn depresja często objawia się w nieswoisty sposób, co może wpływać na niedokładne oszacowanie faktycznej liczby chorych [3]. Zaburzenia depresyjne wykazują ścisły związek z tendencjami samobójczymi [4]. W większości krajów samobójstwa znajdują się w pierwszej dziesiątce najczęstszych przyczyn zgonów, a wśród osób w przedziale wiekowym 15-29 lat jest to druga przyczyna śmierci [5]. W Polsce liczba samobójstw, mimo zauważalnego spadku w latach 2015-2018, jest nadal bardzo wysoka i przekracza pięć tysięcy osób rocznie (przewyższa liczbę ofiar wypadków samochodowych). Obserwuje się też bardzo wysoki procent $(6: 1)$ umierających śmiercią samobójczą mężczyzn w stosunku do kobiet [6].

Mężczyźni podejmujący próby samobójcze czynią to znacząco częściej niż kobiety, będąc pod wpływem alkoholu bądź narkotyków. Silniejszy jest u nich również związek pomiędzy nadużywaniem/uzależnieniem od alkoholu a występowaniem zaburzeń depresyjnych $[7,8]$.

Niniejsza publikacja stanowi przegląd piśmiennictwa, w którym omawia się występujące u mężczyzn zależności pomiędzy depresją, uzależnieniami i tendencjami samobójczymi. Głównym celem było zwrócenie uwagi na zaburzenia depre- 
ness about depressive disorders occurring in men, their specificity and aetiology. This knowledge may improve preventive measures of suicide in men.

\section{THE SYNDROME OF MALE DEPRESSION AND ITS CAUSES}

The incidence of diagnosed depressive disorders among women $(20-25 \%)$ is roughly twice as large as in men (7-12\%). However, the opposite correlation is true when it comes to committed suicides - in Poland men commit suicides almost six times more often than women [2]. One of possible explanations of this discrepancy is that depression in men has unspecific symptoms and they are more difficult to perceive and to diagnose. Moreover, the specificity of depressive disorders among men also can be influenced by behavioural traditional norms and roles attributed to men [10].

One of the first research studies on male depression syndrome is connected with an educational programme conducted in Gotland (Sweden), in the 1980s [11]. The programme was directed to family doctors and its main aim was to prevent suicides. Its goal was to diagnose depression early enough to treat and prevent suicidal attempts. The implementation of the programme caused a significant decrease in suicide frequency. The research showed that early diagnoses and treatment of depression are important ways of suicide prevention. However, further analyses demonstrated that reduction of the suicide rate occurred mainly among women, but it practically did not change among men.

Scientists implemented another educational programme for family doctors in the 1990s and obtained similar results. Those results confirmed the differences between genders, as far as symptoms of depression are concerned, and showed the occurrence of unspecific symptoms of depression especially in males [10].

A study conducted by Cleary [12], which included men after their suicide attempts, confirmed that symptoms of depression among men might not be listed in the standard diagnostic criteria. That could lead to misdiagnosis and an inaccurate estimation of the actual number of people suffering from depression. Most of the participants reported the experience of very high emotional pain before taking the decision about committing suicide. They were not able to precisely identify their symptoms; neither did they try to seek any help. Participants used alcohol or drugs to cope with their mental pain very often. This only made their situation worse, to the point where death seemed like the only option of reducing their pain.

Prior to the suicide attempt, men seek help significantly less frequently than women do. Moreover, once men finally see a doctor, the symptoms of the illness are very severe. They have also difficulties to describe the symp- syjne występujące u mężczyzn i uwarunkowania, które wpływają na ich przebieg. Wydaje się to szczególnie istotne, gdyż - jak wskazuje analiza danych - przedmiotem badań naukowych znacznie częściej (3:1) jest depresja u kobiet niż u mężczyzn [9].

\section{SYNDROM MĘSKIEJ DEPRESJI I JEJ PRZYCZYNY}

Ryzyko wystąpienia zaburzeń depresyjnych u kobiet (20-25\%) jest około dwukrotnie większe niż u mężczyzn (7-12\%), choć w przypadku liczby popełnionych samobójstw stwierdza się zwykle odwrotną zależność, np. w Polsce mężczyźni popełniają samobójstwa prawie sześć razy częściej niż kobiety [2]. Jedna z hipotez próbujących wyjaśnić te rozbieżności zakłada, że depresja u mężczyzn ma odmienny niż u kobiet obraz kliniczny - występuje więcej objawów nieswoistych, słabiej zauważalnych dla otoczenia i trudniejszych do zdiagnozowania. Ponadto występowanie i natężenie objawów jest powiązane $\mathrm{z}$ tradycyjnymi normami i rolami przypisywanymi mężczyznom [10].

Początki naukowej refleksji na temat syndromu męskiej depresji są związane z programem edukacyjnym przeprowadzonym na Gotlandii (Szwecja) w latach 80. XX w. [11]. Był skierowany do lekarzy pierwszego kontaktu i dotyczył depresji kobiet i mężczyzn oraz zapobiegania samobójstwom. Został opracowany z uwzględnieniem typowych objawów depresji. Wprowadzenie programu spowodowało duży spadek częstości samobójstw, a wyniki dostarczyły dowodów na to, że wczesne rozpoznanie i odpowiednie leczenie depresji są ważnymi sposobami zapobiegania samobójstwom. Dalsze analizy wykazały jednak, że zmniejszenie wskaźnika samobójstw nastąpiło głównie w grupie kobiet, wśród mężczyzn zasadniczo nie uległ on zmianie.

Badacze przeprowadzili powtórny program edukacyjny dla lekarzy podstawowej opieki zdrowotnej w latach 90. i otrzymali podobne wyniki. To dało podstawy do wyciągnięcia wniosku o występowaniu różnic między płciami $\mathrm{w}$ zakresie typowych objawów choroby i potwierdzenia hipotezy, że u mężczyzn występują objawy nietypowe, nierozpoznawane przez ówczesne systemy diagnostyczne [10].

Hipotezę, że u mężczyzn chorujących na depresję zgłaszane objawy mogą nie być ujęte w standardowych kryteriach diagnostycznych, co prowadzi do nieprawidłowego rozpoznania, a przez to niedokładnego oszacowania liczby faktycznych przypadków depresji, potwierdziło też badanie Cleary [12], w którym uczestniczyli mężczyźni po poważnej próbie samobójczej. $Z$ przeprowadzonych z nimi rozmów wynikało, iż przed podjęciem decyzji o pozbawieniu się życia prawie wszyscy doświadczali bardzo wysokiego poziomu emocjonalnego cierpienia (bólu), którego jednak nie ujawniali otoczeniu; nie potrafili także dokładnie zidentyfikować swoich objawów i nie szukali pomocy. Aby poradzić sobie z odczuwanym bólem psychicznym, najczęściej pili alkohol lub zażywali narkotyki. To dodatkowo pogarszało ich stan, aż w końcu prowadziło do sytuacji, w której śmierć wydawała się jedyną możliwością przerwania odczuwanego cierpienia. 
Depression in males - specificity, aetiology, relationships with suicidal tendencies and the psychoactive substances usage - literature overview Depresja u mężczyzn - specyfika, etiologia i zwiq̨zki z tendencjami samobójczymi oraz używaniem substancji psychoaktywnych - przegląd piśmiennictwa

toms [9]. Alexithymia is also common among men. Men also often forget or falsely minimise their symptoms. They deliberately do not mention their symptoms when they feel that they may be excluded from an important social group or there is a risk of losing reputation because of the disorder [13]. They notice fewer symptoms even if the symptoms significantly influence their lives [3].

The results obtained by Oliffe et al. [14] show that men rarely seek for their relatives' help in solving their problems. It is believed that it might be related to fear of stigma, which might lead to lower self-esteem and feeling shame. This results in the suppression of emotions and unacceptance of their own limitations of coping with difficult situations.

Meta-analyses conducted by Cavanagh et al. [15] and Winkler et al. [16] showed that men in depression report difficulties with problems solving and controlling their emotions. They also more often present risky behaviours [17]. The symptoms of male depression include aggression, burst of anger and psychoactive substances abuse (alcohol, drugs and nicotine) [10]. Table 1 presents the dominating symptoms of male depression.

Men suffering from depressive disorders rarely feel and show sadness, feeling of guilt, helplessness or hopelessness [10].

Studies by Rice et al. [18] indicate six characteristic symptoms of male depression, i.e. suppression of emotions, alcohol or drugs use, anger and aggression manifestation, somatic symptoms and risky behaviours. They may mislead the doctor and wrongly affect the diagnosis. Men in depression present predominantly externalising symptoms, especially those related to social behaviours, such as bursts of anger, irritation, increased sexual activity, workaholism, emotional withdrawal (with the inability to cry), anhedonia, alexithymia, isolation from the surrounding world, acts of violence and auto-aggression. A detailed list of symptoms of male depression is presented in Table 2.

As described by Dudek [3], a depressive man secludes himself from the society and his relatives; he hurts others to protect himself from his own emotions and engages in auto-destructive behaviours.

A study by Talarowska et al. [20] suggests a significantly less incidence of depressive disorders symptoms in men, such as hypochondria and hysteria, than in women. Men received also lower scores in:

- the subjective feeling of depression (they mostly do not show their dissatisfaction, nervousness, difficulties with attention, the feeling of inferiority and inadaptability, low self-confidence or fear),

- difficulties in physical functioning (they do not focus on their health condition), and

- mental dementia (they do not show a decrease in energy, trust in oneself, pessimism and impaired attention).
Przed popełnieniem samobójstwa mężczyźni istotnie rzadziej niż kobiety poszukują jakiejkolwiek pomocy (także ze strony placówek zajmujących się zdrowiem psychicznym), a gdy już trafią do specjalisty, objawy choroby są $\mathrm{u}$ nich bardzo nasilone, a dodatkowo wielu $\mathrm{z}$ nich ma problem z opisaniem dolegliwości [9]. Wśród mężczyzn częsta jest aleksytymia. Zdarza się również, że zapominają albo minimalizują objawy. Nie zgłaszają objawów również wówczas, gdy wydaje się im, że może to grozić wykluczeniem $\mathrm{z}$ ważnej dla nich grupy społecznej i utratą reputacji [13]. Zwracają uwagę na mniejszą liczbę objawów, nawet jeśli mają one znaczący wpływ na ich funkcjonowanie [3].

Z badania Oliffe i wsp. [14] wynika, że mężczyźni rzadziej korzystają ze wsparcia bliskich w celu rozwiązania problemów. Uważa się, że jest to związane z obawą przed stygmatyzacją, która bezpośrednio przekłada się na obniżenie poczucia własnej wartości i poczucie wstydu. Skutkuje to tłumieniem uczuć i brakiem akceptacji tego, że w życiu zdarzają się okoliczności, w których umiejętności radzenia sobie z nowymi i trudnymi sytuacjami są ograniczone.

Metaanalizy przeprowadzone przez Cavanagh i wsp. [15] oraz Winklera i wsp. [16] wykazały, że mężczyźni $\mathrm{z}$ depresją częściej niż kobiety zgłaszają problemy z rozwiązywaniem problemów i kontrolą impulsów, a także są narażeni na zwiększone ryzyko podejmowania zachowań ryzykownych [17]. Do objawów męskiej depresji zalicza się agresję, wybuchy złości i nadużywanie substancji psychoaktywnych (alkohol, narkotyki, nikotyna) [10]. W tabeli 1 przedstawiono dominujące objawy męskiej depresji.

Mężczyźni chorujący na zaburzenia depresyjne rzadko odczuwają i sygnalizują smutek, poczucie winy, bezradność i beznadziejność [10].

Badanie Rice’a i wsp. [18] wskazuje na sześć objawów charakterystycznych dla męskiej depresji: tłumienie emocji, picie alkoholu, zażywanie narkotyków, manifestowanie złości i agresji, objawy somatyczne oraz podejmowanie zachowań ryzykownych, które mogą mylić lekarza przy próbie ustalenia rozpoznania. U mężczyzn przeważają zatem objawy eksternalizacyjne, szczególnie dotyczące zachowań społecznych: wybuchy wściekłości, poirytowanie, ucieczka w zwiększoną aktywność seksualną, pracoholizm, wycofanie emocjonalne ( $\mathrm{z}$ niezdolnością do płaczu), anhedonia, alekstymia, odcinanie się od świata, akty przemocy, autoagresja. Przegląd objawów męskiej depresji prezentuje tabela 2.

Jak opisuje Dudek [3], depresyjny mężczyzna zamyka się w sobie, odsuwa od bliskich, wycofuje albo, broniąc się przed własnymi emocjami, rani innych, ucieka w zachowania autodestrukcyjne.

Badanie Talarowskiej i wsp. [20] wskazało na zdecydowanie rzadsze występowanie u mężczyzn takich objawów zaburzeń depresyjnych, jak hipochondria i histeria. Mężczyźni uzyskali również niższe wyniki, jeżeli chodzi o:

- subiektywne poczucie depresji (rzadziej niż kobiety ujawniali niezadowolenie, nerwowość, trudności z koncentracją uwagi, poczucie niższości i nieprzystosowania, niskie zaufanie do siebie czy bojaźliwość), 
Table 1. Dominating symptoms of male depression

Tabela 1. Dominujące objawy męskiej depresji

\begin{tabular}{|l|}
\hline Significant decrease in stress resistance/Znaczny spadek odporności na stres \\
\hline Burnout/Wypalenie zawodowe \\
\hline Subjective feeling of constant pressure and tension/Subiektywne poczucie stałej presji i napięcia \\
\hline Withdrawal from relations with family and friend/Wycofanie z relacji rodzinnych i przyjacielskich \\
\hline $\begin{array}{l}\text { No previous (or much less common) problems with impulse control/Niewystępujące wcześniej (albo występujące w znacznie mniejszym } \\
\text { stopniu) problemy z kontrolą impulsów }\end{array}$ \\
\hline Suppressing emotion (especially sad ones)/Tłumienie emocji (zwłaszcza przykrych) \\
\hline Somatic complaints/Nieokreślone dolegliwości somatyczne
\end{tabular}

Source: In-house study on the basis of (10)/Źródło: Opracowanie własne na podstawie (10)

Table 2. Other symptoms of male depression

Tabela 2. Inne objawy męskiej depresji

Discrepancy between the expectations from their gender role and the degree of the fulfilment of these expectations/

Rozbieżność między oczekiwaniami wynikającymi z roli płciowej a poziomem ich spełnienia

Extension of the distance and independence in interpersonal relations, social withdrawal, escalation of conflicts and anger

in contacłs with others/Wzrost dystansu i niezależności w relacjach interpersonalnych, wycofanie społeczne, nasilenie konfliktów i złości w kontaktach z innymi

Low self-esteem and low self-respect (narcissistic wound), disappointment with oneself/Poczucie zagrożenia samooceny

i poszanowania siebie (narcystyczna rana), rozczarowanie soba

Alcohol abuse and other addictions/Nadużywanie alkoholu i inne uzależnienia

Inability to cry/Niezdolność do płaczu

Manifestation of antisocial, narcissistic or compulsive behaviours/Manifestacja zachowań antyspołecznych, narcystycznych

lub kompulsywnych

Loss of interest in sex with concurrent preservation of sexual activity/Utrata zainteresowania seksem, przy jednoczesnym utrzymaniu aktywności seksualnej

Somatic symptoms/Dolegliwości somatyczne

Problems and conflicts at work/Problemy i konflikty w pracy

Problems with concentration and motivation/Problemy z koncentracją i motywacja

Source: In-house study on the basis of (19)/Źródło: Opracowanie własne na podstawie (19)

Burns et al. [21] indicates that men report increased symptoms of depressive disorders in the years prior their death.

It was proved that mood regulation mechanism in women is focused on emotions while in men - on solving problems directly [22].

Results of the Martin et al's study [23] demonstrate that correct identification of male depression symptoms would lead to significant increase in the correct diagnosis of this disorder in the mentioned group. Despite many scientific research studies proving unspecific symptoms of depression in men listed above, they have not been taken into account in diagnostic criteria of depression yet.

There is some evidence that symptoms typical for male depression also may occur in depressive women [24]. Some men suffering from depressive disorders may meet the criteria of male depression, but others can present the "classical depression" symptoms [25].

Men as well as women often think of seeking specialists' help; however, definitely fewer men implement
- trudności w funkcjonowaniu fizycznym (rzadziej niż kobiety koncentrowali się na stanie zdrowia) oraz

- stępienie psychiczne (rzadziej wykazywali obniżoną energię, poczucie niskiej wartości, niskie zaufanie do siebie, pesymizm i osłabioną koncentrację uwagi).

Według Burns i wsp. [21] mężczyźni zgłaszają więcej objawów zaburzeń depresyjnych w latach poprzedzających ich śmierć.

Udowodniono, że mechanizm regulacji nastroju u kobiet jest skoncentrowany na emocjach, podczas gdy u mężczyzn bezpośrednio na rozwiązaniu problemu [22]

Badanie Martin i wsp. [23] wykazało, że uwzględnienie objawów charakterystycznych dla męskiej depresji w diagnozowaniu tej choroby spowodowałoby tak duże zwiększenie częstości jej rozpoznawania u mężczyzn, że częstość występowania u nich depresji stałaby się porównywalna z częstością jej rozpoznawania u kobiet. Pomimo wielu dowodów naukowych na występowanie odmiennych objawów depresji u mężczyzn nie zostały one dotąd uwzględnione w obowiązujących kryteriach diagnostycznych. 
this idea into real life [3]. Usually, men try to treat their problems on their own instead of consulting a doctor. Such behaviour may be related to the stereotype of masculinity where depression and its symptoms are perceived as unmanly and embarrassing. This kind of attitude may be the consequence of difference in social perception of female and male behaviours, where a man appears as a strong and mentally resilient person.

Boys are taught independence since their early childhood. They are fated to their superior role in society. They are being convinced about their strength and unlimited possibilities, so they stop the development of behaviours which show weakness, helplessness or are excessively emotional. A true "macho" cannot be too sensitive, and he should not feel any suffering [3]. The study conducted by Hammen and Peters [26] show that the society does not expect men to express their emotions or share their problems. The society reacts with anger and rejection when noticing any weakness, deepening the crisis in men. Only few men can reach the stereotype of the "strong" man who possesses the power and prestige. That may lead to frustration and chronic conflicts, and thus to aggression, violence and destructive behaviours. Numerous studies confirmed that high focus on stereotypical male behaviours and norms lead to lesser care of physical needs, worsening of mental status, higher risk of depression and suicidal attempts [24]. The study by Oliffe et al. [27] shows that men who met the traditional norms of masculinity were more prone to the depression and were less willing to seek help. A systematic review by Seidler et al. [28] revealed that the traditional stereotype of masculinity may inhibit help-seeking and reinforce maladaptive coping styles. Call and Shafer [29] report that men meeting criteria of the "classic depression" were more prone to seek help in mental health centres comparing to men with dominated "male" symptoms.

What is interesting, the process of adaptation to behaviours typical to the gender role takes place in puberty. The number of children who suffer from depression is similar in both sexes, with slight predominance of boys. However, the significant positive correlation between aggressive behaviours as symptoms of depression and suicidal tendencies in boys become more obvious during their puberty [10].

Low level of testosterone contributes to the neuropsychiatric symptoms, such as irritability, low libido, attention deficit and malaise. However, it is not clear whether the low level of testosterone is the real cause of depressive disorders [30]. Men have ejection of cortisol and testosterone (combat strategy) when they received the situation as it can threat their social status [24].

Chodkiewicz [31] proposed a pattern of development of male depression. The presence of life difficulties accompanied by intense stress, mental suffering or humilia-
Niektóre dowody wskazują, że objawy depresji charakterystyczne dla mężczyzn mogą się też przejawiać $\mathrm{u}$ kobiet $\mathrm{z}$ depresją, co powoduje niejasność $\mathrm{w}$ zakresie specyficznych objawów depresji u mężczyzn i kobiet [24]. Część mężczyzn chorujących na zaburzenia depresyjne spełnia kryteria męskiej depresji, a część depresji „klasycznej" [25].

Mężczyźni i kobiety równie często rozważają zwrócenie się o pomoc, jednak zdecydowanie mniej mężczyzn wciela ten zamiar w życie [3]. Mężczyźni, zamiast zgłosić się do lekarza, często przez długi czas próbują sami leczyć swoje problemy. Takie zachowanie może być związane ze stereotypem męskości - depresja i jej objawy postrzegane są bowiem jako niemęskie i wstydliwe. Podejście to jest konsekwencją różnic społecznego postrzegania zachowań kobiet i mężczyzn, w którym mężczyzna jest osobą silną i odporną psychicznie. Już w dzieciństwie chłopcy uczeni są niezależności i aktywności, wpaja im się nadrzędną rolę w społeczeństwie, przekonuje o sile i nieograniczonych możliwościach, blokując rozwój zachowań wyrażających słabość, bezradność czy nadmierną emocjonalność. Prawdziwy "macho” nie może być zbyt wrażliwy, nie powinien odczuwać cierpienia [3]. Badanie Hammena i Petersa [26] udowodniło, iż otoczenie mężczyzn nie spodziewa się, że będą oni okazywali emocje czy zwierzali się ze swoich problemów/przygnębienia, dlatego też w takiej sytuacji otoczenie najczęściej reaguje wrogością i odrzuceniem, pogłębiając kryzys mężczyzn. Stereotyp „silnego" mężczyzny, mającego władzę i prestiż jest możliwy do osiągnięcia tylko dla niewielu z nich, co może rodzić frustrację i przewlekły konflikt, a co za tym idzie agresje, zachowania przemocowe i destrukcyjne. W wielu badaniach potwierdzono, że im wyższa orientacja na stereotypowe zachowania i normy męskie, tym mniejsza troska o zdrowie fizyczne, gorszy stan zdrowia psychicznego, więcej zachowań eksternalizacyjnych, wyższe ryzyko depresji oraz zachowań samobójczych [24]. Wyniki badania Oliffe i wsp. [27] wykazały, że mężczyźni, którzy podporządkowywali się tradycyjnym normom męskości, byli bardziej podatni na wystąpienie depresji i mniej chętni do poszukiwania pomocy. Przegląd systematyczny dokonany przez Seidlera i wsp. [28] ujawnił, że funkcjonowanie tradycyjnego stereotypu męskości ma wpływ na zaburzenia depresyjne występujące u mężczyzn: na objawy depresji, nastawienie mężczyzn, ich intencje i zachowania związane z poszukiwaniem pomocy oraz rodzaje terapii i strategie radzenia sobie z chorobą. Badanie Call i Shafer [29] dowiodło, że mężczyźni spełniający kryteria „klasycznej” depresji byli bardziej skłonni do poszukiwania pomocy ze strony placówek zajmujących się zdrowiem psychicznym, niż mężczyźni, u których dominowały „męskie” objawy.

Co ciekawe, podejmowanie prób dostosowywania się do zachowań adekwatnych dla własnej płci odbywa się dopiero w okresie dojrzewania. Wcześniej wśród dzieci liczba 
tion might be first symptoms. In some, they may be suppressed by psychoactive substances abuse. At this stage, first symptoms of male depression occur. The attempt to suppress emotion for a longer period of time intensifies the symptoms of the disease. When mental pain becomes difficult to bear, it disturbs everyday life. At this stage, symptoms are severe and very often new ones emerge. It is also a phase of possible addiction to psychoactive substances because they can give temporary relief. In consequence, those actions may lead to suicidal thoughts. Mostly, only in those situations some men will begin to seek help.

There are numerous tools designed to estimate the risk of depressive disorder. Most of them are based on the classic criteria for depression. The use of these tools, in order to diagnose male depression, may give false negative results. Therefore several new diagnostic methods were created, based on unspecific symptoms of male depression. The most well-known tool is the Gotland Male Depression Scale (GMDS) by Rutz. The scale has good psychometric properties. It was adapted in many countries, e.g. in Italy, China, Iceland and also in Poland. Other noteworthy tools are Male Depression Risk Scale (MDRS-22) by Rice et al. (2013) and Masculine Depression Scale (MDS) by Magovcevic and Addis (2008) [10]. It should be kept in mind that those tools can be used only as supporting the diagnosis process.

\section{DEPRESSION AND PSYCHOACTIVE SUBSTANCE USE: AN EXAMPLE OF ALCOHOL ABUSE}

Many studies confirm that people with depressive disorders are more susceptible to drinking alcohol as a form of self-medication [3]. The existence of a mental disorder may additionally be a catalyst for abusive drinking and alcohol addiction [32]. On the other hand, depression can develop as a secondary disorder of alcohol abuse.

A study by Cavanagh et al. [33] indicates that men are more prone to the depression and alcohol abuse coexistence than women. A study by Bazargan-Hejazi et al. [34] shows that men abusing alcohol report serious symptoms of depressive disorders 2.5 times more often in comparison to men not addicted to alcohol. This result contradicts "tension reduction" hypothesis, which assumes that men's alcohol abuse is a mechanism that protects them against depressive symptoms [35].

Whitley et al. [36] claim that men who reported higher levels of compliance with male norms (Table 3) and use less of protective behavioural strategies (Table 4) are more susceptible to more hazardous and harmful alcohol consumption. zachorowań na depresję jest u obu płci zbliżona, a nawet notuje się niewielką przewagę depresji u chłopców. Dopiero w okresie dojrzewania uwidacznia się u chłopców wyraźna zależność między zachowaniami agresywnymi jako objawami depresji i tendencjami samobójczymi [10].

Niski poziom testosteronu przyczynia się do wystąpienia objawów neuropsychiatrycznych, takich jak: drażliwość, niskie libido, obniżenie koncentracji i złe samopoczucie, ale nie jest jasne, czy odpowiada on za rozwój zaburzeń depresyjnych [30]. U mężczyzn zaobserwowano wyrzut kortyzolu i testosteronu (strategia walki), gdy odbierali oni sytuację jako zagrażającą ich statusowi społecznemu [24].

Chodkiewicz [31] zaproponował możliwy schemat opisujący rozwój męskiej depresji. Wystąpienie trudności życiowych, którym towarzyszy silny stres, cierpienie psychiczne bądź upokorzenie, jest najpierw tłumione poprzez nadużywanie substancji psychoaktywnych. Na tym etapie pojawiają się pierwsze objawy męskiej depresji. Podjęcie dłuższej próby tłumienia emocji pogłębia objawy choroby. Gdy ból psychiczny staje się trudny do zniesienia, zaczyna przeszkadzać w codziennym funkcjonowaniu. Na tym etapie nadal pogłębiają się objawy, a także często pojawiają się nowe. Jest to również moment, w którym może dojść do rozwoju uzależnienia od substancji psychoaktywnych, które dotychczas przynosily chwilową ulgę. Takie postępowanie może doprowadzić w konsekwencji do podjęcia zachowań samobójczych. Najczęściej dopiero w takich sytuacjach niektórzy mężczyźni zaczynają szukać pomocy.

Istnieje wiele narzędzi przeznaczonych do określania prawdopodobieństwa wystąpienia zaburzeń depresyjnych. Większość z nich opiera się na klasycznych kryteriach depresji. Użycie tych narzędzi w przypadku syndromu męskiej depresji może spowodować zafałszowanie wyników, dlatego zostało stworzonych kilka nowych metod diagnostycznych, które opierają się na nietypowych objawach depresji. Najbardziej znana jest Gotland Male Depression Scale (GMDS) Rutza. Skala, cechująca się dobrymi właściwościami psychometrycznymi, została zaadaptowana w kilku krajach, m.in. we Włoszech, Chinach, Islandii. Również jej polska adaptacja, dokonana przez Chodkiewicza, wskazuje na dobre właściwości psychometryczne. Warte uwagi są też takie narzędzia, jak Male Depression Risk Scale (MDRS-22) autorstwa Rice'a i wsp. (2013) i Masculine Depression Scale (MDS) Magovcevic i Addisa (2008) [10]. Należy jednak pamiętać, że narzędzia te mogą pełnić jedynie funkcję pomocniczą $\mathrm{w}$ diagnozie.

\section{DEPRESJA A UŻYWANIE SUBSTANCJI PSYCHOAKTYWNYCH NA PRZYKŁADZIE NADUŻYWANIA ALKOHOLU}

Liczne badania potwierdzają, że osoby z zaburzeniami depresyjnymi są bardziej podatne na częstsze picie alkoholu jako formę samoleczenia [3]. Pierwotne występowanie zaburzenia psychicznego może sprzyjać nadmiernemu piciu i rozwojowi uzależnienia od alkoholu, zarazem picie alkoho- 
Rol and Chodkiewicz [39] observed a positive correlation between impulsiveness, aggressiveness and depression in men who are addicted to alcohol. The assessment of factors influencing the occurrence of depressive symptoms in addicted people seems to be extremely important, especially in the context of the treatment improvement. According to the available data, it is needed to prepare and implement interventions which would decrease the risk of drinking among people with suicidal thoughts.

\section{DEPRESSION AND SUICIDAL TENDENCIES}

In 2018, in Poland, 5182 cases of suicide were registered. There were 4471 male victims and 711 female victims [40]. The difference between these two numbers is explained by the fact that men are choosing more effective methods of suicide. Men seek help less often and more frequently reach for alcohol and drugs leading easily to the decision to commit suicide [41]. The suicidal process (time from the first suicidal thought to the moment of effective suicide) is shorter in men than in women. It is difficult to explain why women choose less effective ways of committing suicide. It cannot be assumed that they are not aware that some of the methods are less effective than others. There is a possibility that they do not want to die in fact.

According to Oquendo's et al. [42], the risk of the future suicidal behaviour in men is higher when there is (1) a family history of suicide, (2) a history of alcohol use, (3) a personality disorder, e.g. borderline, (4) a history of smoking cigarettes and (5) an early separation from parents.

Suicide process (time since suicidal thoughts occurred to death) is shorter in men than women. Men show increased symptoms of depressive disorder in the years before the death, unlike women who were not reported aggravation of depressive symptoms [39].

Pirkis et al. [43] aimed at finding the correlation between certain features of typical masculinity and the occurrence of suicidal thoughts. The researchers show that self-sufficiency is perceived as typical trait of masculinity, which may affect the risk of the onset of suicidal thoughts in men. Men who feel self-sufficient think that they should be strong in the face of any problems and may not show any behaviour which might be regarded as a sign of their weakness. As a result, they often do not ask for help neither family members, friends nor professionals. An unsuccessful suicide attempt may be a reason for shame for men. Such failure may contribute to the opinion that the man is loser who is not able to even end his life successfully. Similar feelings may appear in the surroundings of the survivor, which can increase his feeling of remorse lu może być metodą „samoleczenia” objawów współwystępujących zaburzeń psychicznych, prowadząc do używania szkodliwego, a w konsekwencji często do uzależnienia [32].

Badanie Cavanagh i wsp. [33] wskazuje, że mężczyźni są bardziej narażeni na współwystępowanie depresji i nadużywania alkoholu niż kobiety. Badanie Bazargan-Hejazi i wsp. [34] wykazało, iż mężczyźni nadużywający alkoholu 2,5 razy częściej zgłaszają występowanie poważnych objawów zaburzeń depresyjnych w porównaniu z mężczyznami, którzy nie nadużywają alkoholu. Wynik ten stoi w sprzeczności z hipotezą „redukcji napięcia”, która zakłada, iż nadużywanie alkoholu przez mężczyzn jest mechanizmem, który chroni ich przed objawami depresji [35].

W badaniu Whitley i wsp. [36] mężczyźni zgłaszający wyższe poziomy zgodności z normami męskimi (tab. 3) i niższe poziomy stosowania ochronnych strategii behawioralnych (tab. 4) wykazywali tendencję do najbardziej niebezpiecznego spożywania alkoholu.

W badaniu Rol i Chodkiewicza [39] zauważono dodatnią korelację pomiędzy impulsywnością i agresywnością a depresją u mężczyzn uzależnionych od alkoholu. Ocena czynników wpływających na występowanie objawów depresyjnych u osób uzależnionych wydaje się niezwykle ważna w kontekście wpływu depresyjności na wyniki leczenia. Naturalną konsekwencją badań w tym kierunku może być opracowanie interwencji mających na celu zmniejszenie ryzyka nawrotu picia i prób samobójczych, często występujących w grupie osób uzależnionych od alkoholu.

\section{DEPRESJA A TENDENCJE SAMOBÓJCZE}

W Polsce w roku 2018 popełniono ogółem 5182 samobójstw, a wśród ofiar było 4471 mężczyzn i 711 kobiet [40]. Różnica między mężczyznami a kobietami pod względem liczby zamachów samobójczych zakończonych zgonem jest tłumaczona faktem, iż mężczyźni wybierają bardziej skuteczne metody odbierania sobie życia, rzadziej szukają pomocy i częściej sięgają po alkohol i narkotyki, co sprzyja podjęciu decyzji o odebraniu sobie życia [41]. Trudno jednak wyjaśnić, dlaczego kobiety wybierają mniej ryzykowne sposoby popełniania samobójstw, nie można przecież zakładać, że nie są świadome tego, że niektóre metody są skuteczniejsze niż inne.

Według badań Oquendo i wsp. [42] u mężczyzn ryzyko przyszłych zachowań samobójczych jest zwiększone w przypadku: rodzinnego obciążenia samobójstwem, używania narkotyków w wywiadzie, zaburzeń osobowości typu borderline, palenia tytoniu i wczesnej separacji od rodziców.

Proces samobójczy (czas od wystąpienia myśli samobójczych do skutecznego odebrania sobie życia) jest krótszy u mężczyzn niż u kobiet. Mężczyźni wykazują zwiększone objawy zaburzeń depresyjnych $\mathrm{w}$ latach poprzedzających śmierć, w przeciwieństwie do kobiet, u których nie zanotowano nasilenia objawów depresyjnych [39]. 
Table 3. Behaviours classification of masculine norms according to the Conformity to Masculine Norms Inventory Tabela 3. Klasyfikacja zachowań norm męskich zgodnie z Conformity to Masculine Norms Inventory

\begin{tabular}{|l|}
\hline Winning/Wygrywanie \\
\hline Emotional control/Kontrola emocji \\
\hline Risk-taking/Podejmowanie ryzyka \\
\hline Violence/Przemoc \\
\hline Dominance/Dominacja \\
\hline Playboy/Lekkoduszność \\
\hline Self-reliance/Samowystarczalność \\
\hline Primacy of work/Prymat pracy \\
\hline Power over women/Władza nad kobietami \\
\hline Disdain for homosexuals/Pogarda dla homoseksualistów \\
\hline Pursuit of status/Dążenie do odpowiedniego statusu \\
\hline Source: Own elaboration on the basis of (37)/Žródło: Opracowanie własne na podstawie (37)
\end{tabular}

Table 4. Protective behavioural strategies according to the Protective Behavioural Strategies Scale Tabela 4. Behawioralne strategie ochronne według Protective Behavioural Strategies Scale

\begin{tabular}{|l|}
\hline Determine not to exceed a certain number of drinks/Ustal, aby nie przekraczać określonej liczby drinków \\
\hline Alternate alcoholic and non-alcoholic drinks/Alternatywne napoje alkoholowe i bezalkoholowe \\
\hline Have a friend to let know when one should stop drinking/Poproś znajomego, aby poinformował cię, kiedy należy przestać pić \\
\hline Leave the bar/party at a predetermined time/Opuść bar/imprezę o określonej godzinie \\
\hline Stop drinking at a predetermined time/Przestań pić we wcześniej ustalonym czasie \\
\hline Drink water while drinking alcohol/Pij wodę podczas picia alkoholu \\
\hline Put extra ice in drink/Włóż dodatkowy lód do drinków \\
\hline Avoid drinking games/Unikaj gier zwiq̨zanych z piciem \\
\hline Drink shots of liquor/Alkohol pij w kieliszkach \\
\hline Avoid mixing different types of alcohol/Unikaj mieszania różnych rodzajów alkoholu \\
\hline Drink slowly, rather than gulp or chug/Pij powoli, zamiast przełykać \\
\hline Avoid trying to "keep up" or out-drink others/Unikaj prób "nadqzżania” lub wypicia więcej niż inni \\
\hline Use a designated driver/Skorzystaj z usług kierowcy \\
\hline Make sure to go home with a friend/Pamiętaj, aby wrócić do domu z przyjacielem \\
\hline Know where the drink has been at all times/Kontroluj, gdzie odstawiasz swojego drinka \\
\hline Source: Own elaboration on the basis of (38)/Źródło: Opracowanie własne na podstawie (38) \\
\hline
\end{tabular}

and embarrassment [3]. The above mentioned study by Cleary [11] indicates that men prior a suicide attempt experienced significant, long-lasting emotional pain, but they did not seek for help. Conclusions from other study, which was performed in boys between 9 and 13 years of age [44], also show correlation between the perception of some behaviours as symptoms of weakness (expressing emotions or seeking for help) and higher risk of suicidal behaviours.

The occurrence of depression in men, the history of hospitalisation and coexistence of other mental disorders, such as alcohol addiction, significantly increase the risk of committing suicide [45]. Blumenthal et al. [46] demonstrate the existence of the "lethal triad of suicide," in which an overlap of impulsive and aggressive personality traits, psychoactive substances abuse and depression
Pirkis i wsp. [43] przeprowadzili badanie, którego celem było odkrycie zależności pomiędzy konkretnymi elementami typowej męskości a występowaniem myśli samobójczych. Badacze wykazali, iż samowystarczalność jest cechą typowo postrzeganej męskości, która może wpływać na ryzyko wystąpienia u mężczyzn myśli samobójczych. Mężczyźni, którzy czują się samowystarczalni, uważają, że powinni być silni w starciu z przeciwnościami losu, a okazywanie gorszego samopoczucia może być dla nich znakiem słabości. W rezultacie często nie widzą możliwości zwrócenia się o pomoc do przyjaciół, rodziny czy profesjonalistów. Warto zauważyć, że nieudana próba samobójcza jest dla mężczyzny powodem do wstydu. Stawia go w roli nieudacznika, który nie potrafi nawet skutecznie zakończyć swojego życia. Podobne odczucia mogą pojawić się również w otoczeniu niedoszłego samobójcy, potęgując wyrzuty sumienia 
is observed. It was proved that the triad occurs more often in men than women. It was found that symptoms of mental disorders occurred in the majority of people who committed suicide (even up to $82 \%$ ). Mainly, it was depression and alcohol abuse [47].

In Poland, the majority of men suffering from depression are between 30 and 49 years of age (about 2.0-2.3\% of all men in this age group) [48]. The number of suicides in this age range has been remaining at a very high level for years.

\section{CONCLUSIONS}

According to the World Health Organisation, depression is a complex problem for public health since it causes disabilities, which might lead to serious physical and mental impairments (including suicide), personal, social and working problems, and it increases costs for the health care [49]. Depression has an impact on the patient's quality of life. Patients with depression very often feel different and not accepted. Depression is frequently associated with low self-esteem and feelings of worthlessness, which may lead to self-discrimination and in consequence break social bonds [50].

The economic costs of depression can be divided into direct and indirect costs. The direct costs of depression include visits and consultations with doctors, hospitalisation, diagnostic tests and medicines. Indirect costs are related to the loss of labour productivity.

Depression is a serious burden on the state budget and may cost Polish society as much as PLN 2.6 million annually. The costs of lost productivity, resulting from one instance of committed suicide by a person aged 25, is estimated at about PLN 597,000. Polish economic losses caused by all suicides committed in Poland are approximately PLN 2 billion yearly [51].

One of the challenges for the public health is the improvement of men's health determinants. Focusing on the male's features, such as courage (expressing emotions is courageous) and leadership (showing others more effective ways of coping with emotional difficulties) are important in this aspect [52].

Screening tests conducted among men in order to detect externalising symptoms of depression seem to be crucial. Moreover, men with suicidal thoughts are not eager to talk about their attempts during medical consultations and they are ashamed to seek help [53]. A better understanding of male depressive symptoms is the main key to provide appropriate support in the management of their emotions [54]. According to Skogman et al. [55], the consideration of gender differences while evaluating the risk of suicide and planning crisis intervention could prevent suicides more efficiently.

In the currently obligatory programme to prevent depression in Poland for 2015 and 2019, the focus of pre- i zażenowanie [3]. Wspominane już badanie Cleary [11] wskazuje, iż mężczyźni przed podjęciem próby samobójczej doświadczali znaczącego, długotrwałego emocjonalnego bólu, nie szukali jednak pomocy. Wnioski z badania przeprowadzonego wśród chłopców w wieku 9-13 lat [44] również wskazują na występowanie związku pomiędzy postrzeganiem pewnych zachowań jako niemęskich objawów słabości (wyrażanie emocji czy poszukiwanie pomocy) a zwiększonym ryzykiem zachowań suicydalnych.

Występowanie u mężczyzn depresji, przebycie hospitalizacji i współwystępowanie innych zaburzeń psychicznych, np. uzależnienia od alkoholu, znacznie zwiększa ryzyko popełnienia samobójstwa [45]. Blumenthal i wsp. [46] wskazali na istnienie tzw. śmiertelnej triady samobójczej, czyli nakładania się impulsywnych i agresywnych cech osobowości, nadużywania substancji psychoaktywnych i depresji. Dowiedziono, że taka triada występuje znacząco częściej u mężczyzn. Stwierdzono, że u większości (nawet $82 \%$ ) osób, które odebrały sobie życie, występowały objawy zaburzeń psychicznych, przy czym najczęściej była to depresja i uzależnienie od alkoholu [47].

Warto zwrócić uwagę na to, że w Polsce najwięcej mężczyzn chorujących na depresję znajduje się w grupie wiekowej 30-49 lat (2,0-2,3\%) [48] i właśnie w tej grupie liczba samobójstw od wielu lat pozostaje na niepokojąco wysokim poziomie.

\section{PODSUMOWANIE}

Według Światowej Organizacji Zdrowia depresja jest złożonym problemem zdrowia publicznego, ponieważ może prowadzić do poważnych fizycznych oraz psychicznych upośledzeń (w tym do samobójstw), osobistych, społecznych i zawodowych problemów, zwiększając tym samym koszty opieki zdrowotnej [49]. Depresja wpływa na jakość życia pacjenta. Pacjenci z depresją bardzo często czują się nieakceptowani. Depresja jest często związana z niską samooceną i poczuciem bezwartościowości, co może prowadzić do samodyskryminacji i w konsekwencji do zerwania więzi społecznych [50].

Koszty ekonomiczne depresji można podzielić na bezpośrednie i pośrednie. Koszty bezpośrednie obejmują wizyty i konsultacje u lekarzy, hospitalizacje, testy diagnostyczne i leki. Koszty pośrednie są związane z obniżoną produktywnością zawodową.

Depresja jest poważnym obciążeniem dla budżetu państwa i może kosztować polskie społeczeństwo ok. 2,6 mln zł rocznie. Koszty utraconej produktywności, spowodowanej jednym przypadkiem samobójstwa osoby $\mathrm{w}$ wieku 25 lat, szacuje się na ok. 597 tys. zł. Straty dla polskiej gospodarki z powodu wszystkich samobójstw popełnianych w ciągu roku szacuje się na ok. 2 mld zł [51].

Wyzwaniem zdrowia publicznego jest m.in. poprawa uwarunkowań zdrowia mężczyzn. Ważne w tym aspekcie jest skupianie się na pozytywnych męskich cechach - odwadze (podkreślenie, że wyrażanie uczuć jest odważne) 
vention is on post-partum depression, adolescent depression and depression occurring in the elderly [56]. There is a lack of coordinated actions focusing on the prevention of depressive disorders among men or control and prevention of coexistence of mental disorders in this group. In Poland, the problem of male depression keeps coming back once in a while. Most often it is raised by non-governmental organisations within the frame of their initiatives or at scientific conferences. Those activities are exceptionally important since there is a lack of other prevention actions.

In 2012, a campaign "Mężczyźni też płaczą" [Men cry, too] was launched, which was initiated by ITAKA Fundation - the Centre for Missing People. The fifth edition of the campaign, called "Twarze depresji. Nie oceniam. Akceptuję" [The faces of depression. I do not judge. I accept], was also devoted to the problem of depression and suicides among men. Many famous men took part in this action. They were sharing their experiences with depression, thereby giving an example of openness to talking about male problems. The goal of these actions was to spread knowledge based on facts about mental disorders among men. There is a need for more comprehensive approach to that problem. Firstly, a detailed analysis, making a diagnosis and developing adequate tools have to be performed. This process should involve men in depression and their nearest environment (including their wives/partners who have a huge impact on their commitment to their own health) and the whole society. More of systemic activities in the public health and healthcare should be planned as well.

In conclusion, there is a need for further research on male depression which would focus on various age and ethnic groups, healthy and ill people and the possibility of coexistence of disorders (personality disorders, primary addictions). It is necessary to conduct a nationwide study consisting of a representative sample of men. That kind of study could be helpful to identify issues and challenges facing the Polish society in order to effectively help men who are in the state of a mental crisis. i przywództwie (pokazanie bardziej efektywnych sposobów radzenia sobie z emocjonalnymi trudnościami) [52].

Prowadzenie badań przesiewowych wśród mężczyzn $\mathrm{w}$ celu wykrycia uzewnętrznionych (externalising) objawów depresji wydaje się konieczne, gdyż mężczyźni, którzy mają myśli samobójcze, nie są chętni do rozmowy o swoich zamiarach podczas konsultacji medycznych i są zawstydzeni wizją szukania pomocy w walce $z$ depresją [53]. Lepsze zrozumienie męskich objawów depresji jest kluczowym krokiem do wspierania mężczyzn w podejmowaniu decyzji w zakresie zarządzania swoim nastrojem [54]. Według Skogmana i wsp. [55] uwzględnienie różnic występujących między płciami przy ocenie ryzyka samobójstwa i planowania interwencji kryzysowej mogłoby spowodować, że zapobieganie samobójstwom byłoby bardziej skuteczne.

W obecnie obowiązującym „Programie zapobiegania depresji w Polsce na lata 2015-2019” działania profilaktyczne zostały skierowane na depresję poporodową, młodzieńczą i występującą wśród osób starszych [56]. Brakuje skoordynowanych działań mających na celu zapobieganie zaburzeniom depresyjnym wśród mężczyzn, jak również kontrolę i profilaktykę współwystępowania innych zaburzeń psychicznych $\mathrm{w}$ tej grupie. W Polsce raz na jakiś czas wraca się do tematu męskiej depresji. Najczęściej ma to miejsce przy okazji kolejnych pojedynczych inicjatyw podejmowanych w tym temacie lub konferencji naukowych. Biorąc pod uwagę brak innych działań profilaktycznych, są one niezwykle ważne.

W 2012 r. prowadzono kampanię pt. „Mężczyźni też płaczą", zainicjowaną przez Fundację ITAKA - Centrum Poszukiwań Ludzi Zaginionych. Również piąta edycja kampanii pt. „Twarze depresji. Nie oceniam. Akceptuję” została poświęcona problematyce depresji i samobójstw u mężczyzn. W akcji tej wzięło udział wielu znanych mężczyzn, którzy dali przykład otwartości na rozmowę o męskich problemach. Celem tych akcji było odczarowanie mitu macho i szerzenie wiedzy na temat zaburzeń psychicznych wśród mężczyzn. Niezbędne jest jednak bardziej kompleksowe podejście do problemu, zaczynając od jego dokładnej analizy, rozpoznania, a następnie opracowania odpowiednich narzędzi angażujących mężczyzn, ich najbliższe otoczenie (przed wszystkim żony/partnerki mające duży wpływ na ich zaangażowanie we własne zdrowie) i całe społeczeństwo. W tym zakresie powinny też zostać zaplanowane działania systemowe z zakresu zdrowia publicznego i opieki zdrowotnej.

Na koniec warto podkreślić potrzebę dalszych badań dotyczących męskiej depresji, uwzględniających m.in. różne grupy wiekowe i etniczne, osoby zdrowe i chore, a także możliwość współwystępowania zaburzeń (np. zaburzeń osobowości, pierwotnych uzależnień). Konieczne wydaje się przeprowadzenie ogólnopolskiego badania obejmującego reprezentatywną próbę mężczyzn, które pozwoliłoby na identyfikację problemów, którymi należałoby się w Polsce zająć, aby móc efektywnie pomagać mężczyznom będącym w kryzysie psychicznym. 
Depression in males - specificity, aetiology, relationships with suicidal tendencies and the psychoactive substances usage - literature overview Depresja u mężczyzn - specyfika, etiologia i zwiq̨zki z tendencjami samobójczymi oraz używaniem substancji psychoaktywnych - przegląd piśmiennictwa

\section{Conflict of interest/Konflikt interesu}

Absent./Nie występuje.

\section{Financial support/Finansowanie}

Absent./Nie występuje.

\section{References/Piśmiennictwo}

1. Vos T, Allen C, Arora M, Barber RM, Bhutta ZA, Brown A, et al. Global, regional, and national incidence, prevalence, and years lived with disability for 310 diseases and injuries, 1990-2015: a systematic analysis for the Global Burden of Disease Study 2015. Lancet 2016; 388: 1545-1602.

2. Elavsky S, Gold C. Gender differences in the relationship between physical activity and depression. Gerontology 2008; $48: 178$.

3. Dudek D. Prawdziwi mężczyźni też płaczą, czyli czy depresja naprawdę jest kobietą? In: Dudek D, Rymaszewska J (eds.). Psychiatria pod krawatem. Warszawa: Medical Education; 2016, p. 179-201.

4. Dumais A, Lesage AD, Alda M, Rouleau G, Dumont M, Chawky N, et al. Risk factors for suicide completion in major depression: a case - control study of impulsive and aggressive behaviors in men. Am J Psychiatry 2005; 162: 2116-2124.

5. WHO. Preventing suicide: A global imperative. 2014. Available at: https://www.who.int/mental_health/suicideprevention/world_report_2014/en/.

6. Policja. Available at: www.statystyka.policja.pl.

7. Klimkiewicz A, Ilgen MA, Bohnert ASB, Jakubczyk A, Wojnar M, Brower KJ. Suicide attempts during heavy drinking episodes among individuals entering alcohol treatment in Warsaw, Poland. Alcohol Alcohol 2012; 47: 571-576.

8. Sharma MK, Salim A. Suicidal behavior among alcohol dependents: relationship with anger and personality dimensions. Ind Psychiatry J 2014; 23: 61-64.

9. Addis ME. Gender and depression in men. Clin Psychol Sci Prac 2008; 15: 153-168.

10. Chodkiewicz J, Miniszewska J. Męska depresja - koncepcja, metody pomiaru i związki z zachowaniami samobójczymi. Psychiatr Psychol Klin 2016; 16: 33-37.

11. Rutz W, Walinder J, Eberhard G, Holmberg G, von Knorring L, Wistedt B, et al. An educational program on depressive disorders for general practitioners on Gotland: background and evaluation. Acta Psychiatr Scand 1989; 79: 19-26.

12. Cleary A. Suicidal action, emotional expression, and the performance of masculinities. Soc Sci Med 2012; 74: 498-505.

13. Addis ME, Mahalik JR. Men, masculinity, and the contexts of help seeking. Am Psychol 2003; 58: 5-14.

14. Oliffe JL, Ogrodniczuk JS, Gordon SL, Creighton G, Kelly MT, Black N, et al. Stigma in male depression and suicide: a canadian sex comparison study. Community Ment Health J 2016; 52: 302-310.

15. Cavanagh A, Wilson CJ, Kavanagh DJ, Caputi P. Differences in the expression of symptoms in men versus women with depression: a systematic review and meta-analysis. Harv Rev Psychiatry 2017; 25: 29-38.

16. Winkler D, Pjrek E, Kasper S. Anger attacks in depression - evidence for a male depressive syndrom. Psychother Psychosom 2005; 74: 303-307.

17. Walinder J, Rutz W. Male depression and suicide. Int Clin Psychopharmacol 2001; 16: 21-24.

18. Rice SM, Fallon BJ, Aucote HM. Development and preliminary validation of the depression risk scale: Furthering the assessment of depression in men. J Affect Disord 2013; 151: 950-958.

19. Pilarska A. Chłopaki nie płaczą... czyli specyfika depresji u mężczyzn. In: Palus K (ed.). Płeć. Między ciałem, umysłem a społeczeństwem. Poznań: Wydawnictwo Naukowe Wydziału Nauk Społecznych UAM; 2011, p. 117-129.

20. Talarowska M, Florkowski A, Zboralski K, Gałecki P. Różnice w przebiegu depresji między kobietami a mężczyznami stwierdzone na podstawie testu MMPI-2. Psychiatr Pol 2010; 44: 319-328.

21. Burns RA, Luszcz MA, Kiely KM, Butterworth P, Browning C, Mitchell P, et al. Gender differences in the trajectories of late-life depressive symptomology and probable depression in the years prior to death. Int Psychogeriatr 2013; 25: 1765-1773.

22. Thayer JR, Rossy LA, Ruiz-Padial E, Johnsen BH. Gender diffrences in relationship between emotional regulation and depressive symptomps. Cogn Ther Res 2003; 27: 349-364.

23. Martin LA, Neighbors HW, Grififth DM. The expirience of symptom of depression in men vs women: analysis of the National Comorbidity Survey Replication. JAMA Psychiatry 2013; 70: 1100-1106.

24. Moller-Leimkuhler AM, Bottlender R, Strauss A, Rutz W. Is there evidence for a male depressive syndrome in inpatients with major depression? J Affect Disord 2004; 80: 87-93.

25. Nadeau MM, Balsan MJ, Rochlen AB. Men's depression: endorsed experiences and expressions. Psychology of Men and Masculinity 2016; 17: 328-335.

26. Hammen CI, Peters SD. Interpersonal consequences of depression: responses to men and women enacting a depressed role. J Abnorm Psychol 1978; 87: 322-332.

27. Oliffe JL, Phillips MJ. Men, depression and masculinities: a review and recommendations. Journal of Men's Health 2008; 5: 194-202. 
28. Seidler ZE, Dawes AJ, Rice SM, Oliffe JL, Dhillon HM. The role of masculinity in men's help-seeking for depression: a systematic review. Clin Psychol Rev 2016; 49: 106-118.

29. Call J, Shafer K. Gendered manifestations of depression and help seeking among men. Am J Men's Health 2018; 2: 41-51.

30. Johnson JM, Nachtigall LB, Stern TA. The effect of testosteron levels on mood in men: a review. Psychosomatics 2013; 54: 509-514.

31. Chodkiewicz J. Polska adaptacja Gotlandzkiej Skali Męskiej Depresji (GDMS) Wolfganga Rutza. Adv Psychiatry Neurol 2017; 26: 13-23.

32. Wyrzykowska E. Nawrót w uzależnieniu od alkoholu jako wyraz depresyjności pacjenta. Psychiatr Psychol Klin 2012; 12: 67-69.

33. Cavanagh A, Wilson CJ, Caputi P, Kavanagh D. Symptom endorsement in men versus women with a diagnosis of depression: a differental item functioning approach. Int J Soc Psychiatry 2016; 62: 1-11.

34. Bazargan-Hejazi S, Bazargan M, Gaines T, Jamanez M. Alcohol misuse and report of recent depression symptoms among emergency department patients. Am J Emerg Med 2008; 26: 537-544.

35. Greeley J, Oei T. Alcohol and Tension Reduction. In: Leonard KE, Blane HT (eds.). Psychological Theories of Drinking and Alcoholism. New York: Guilford; 1999, p. 14-53.

36. Whitley RB, Madson MB, Zeigler-Hill V. Protective behavioral strategies and hazardous alcohol use among male college students: conformity to male gender norms as a moderator. Psychology of Men and Masculinity 2018; 19: 477-483.

37. Mahalik JR, Locke BD, Ludlow LH, Diemer MA. Development of the conformity to masculine norms inventory. Psychology of Men and Masculinity 2003; 4: 3-25.

38. Martens MP, Ferrier AG, Sheehy MJ, Corbett K, Anderson DA, Simmons A. Development of the protective behavioral strategies survey. Journal of Studies on Alcohol 2005; 66: 698-705.

39. Rol P, Chodkiewicz J. Objawy atypowej depresji u mężczyzn uzależnionych od alkoholu - rola agresywności, impulsywności i bólu psychicznego. Postępy Psychiatrii i Neurologii 2015; 24: 199-207.

40. Główny Urząd Statystyczny. Samobójstwa. 2019.

41. Pawlak J, Miechowicz I, Dmitrzak-Węglarz M, Szczepankiewicz A, Zaremba D, Kapelski P, et al. Czy czynniki związane z ryzykiem samobójstwa są specyficzne dla płci? Psychiatr Pol 2018; 52: 21-32.

42. Oquendo MA, Bongiovi-Garcia ME, Galfalvy H, Goldberg PH, Grunebaum MF, Burke AK, et al. Sex diffrences in clinical predictors of suicidal acts after major depression: a prospective study. Am J Psychiatry 2007; 164: 134-141.

43. Pirkis J, Spittal MJ, Koeogh L, Mousaferiadis T, Currier D. Masculinity and suicidal thinking. Soc Psychiatry Psychiatr Epidemiol 2017; 52: 319-327.

44. Mac An Ghaill MM, Haywood C. Understanding boys': Thinking through boys, masculinity and suicide. Soc Sci Med 2012; 74: 482-489.

45. Ilgen MA, Downing K, Zivin K. Exploratory data mining analysis identifying subgroups of patients with depression who are at high risk for suicide. J Clin Psychiatry 2009; 70: 1495-1500.

46. Blumenthal S. Suicide and gender. Washington DC: American Psychiatric Press; 1992.

47. Henriksson MM, Aro HM, Marttunen MJ. Mental disorders and comorbidity in suicide. Am J Psychiatry 1993; 150: 935-940.

48. Moskalewicz J, Kiejna A, Wojtyniak B. Epidemiologia zaburzeń psychicznych i dostępności do psychiatrycznej opieki zdrowotnej - EZOP Polska. Warszawa: Instytut Psychiatrii i Neurologii; 2012.

49. World Health Organization. 2012. Depression, a Hidden Burden. Available at: http://www.who.int/mental_ health/management/depression.

50. Coretti S, Rumi F, Cicchetti A. The social cost of major, depression. a systematic review. Review of European Studies 2019; 11.

51. Kielan A, Olejniczak D. Czynniki ryzyka oraz konsekwencje zachowań samobójczych z uwzględnieniem problematyki samobójstw dzieci i młodzieży, Dziecko Krzywdzone. Teoria, badania, praktyka 2018; 17.

52. Fogarty AS, Proudfoot J, Whittle EL, Player MJ, Christensen H, Hadzi-Pavlovic D, et al. Men's use of positive strategies for preventing and managing depression: a qualitative investigation. J Affect Disord 2015; 188: 179-187.

53. Rice SM, Oliffe JL, Kealy D, Ogrodniczuk JS. Male depression subtypes and suicidality. Latent profile analysis of internalizing and externalizing symptoms in a representative Canadian sample. J Ner Ment Dis 2018; 206: 169-172.

54. Kilmartin C. Depression in men: communication, diagnosis and therapy. Journal of Men's Health and Gender 2005; 2: 95-99.

55. Skogman K, Alsen M, Ojehagen A. Sex differences in risk factors for suicide after attempted suicide - a follow-up study of 1052 suicide attempters. Soc Psychiatry Psychiatr Epidemiol 2004; 39: 113-120.

56. Minister Zdrowia. Program zapobiegania depresji w Polsce na lata 2015-2019. Warszawa: 2015. 